\title{
An Evaluation Of Income Tax Incentives Available To The South African Oil And Gas Industry
}

\author{
Anneke Maré Moolman, North-West University, South Africa
}

Pieter van der Zwan, North-West University, South Africa

\begin{abstract}
The oil and gas sector is advantageous to South Africa. However, the country's oil and gas reserves are minimal in relation to many other countries, reducing attractiveness to prospective investors. In the aim of promoting investment in the oil and gas sector of South Africa, attraction should be improved by other means, such as an alluring regulatory environment, including the taxation regime.

The research conducted in this study aimed to determine whether the income tax legislation in South Africa provides a meaningful incentive for oil and gas companies to compete for international investment in this industry without unnecessarily compromising the State's share of wealth from the industry. A literature review established the use and characteristics of meaningful tax incentives. The incentives contained in South Africa's oil and gas tax environment were evaluated to determine whether the incentives can attract investment to the sector.

Findings indicate that the incentive contained in the Tenth Schedule generally meets identified characteristics of meaningful tax incentives, enabling South Africa to lure investment to the sector. The interaction between this incentive and the remainder of the legislation, however, reduces the stability afforded to investors and may create uncertainty in the application of the incentive. Also, an apparent lack of monitoring of the regime may result in the impact and necessity of the incentive not being determinable, especially if the investor environment were to be affected by new discoveries.
\end{abstract}

Keywords: Income Tax On Petroleum; Income Tax On Gas Companies; South Africa; Tenth Schedule; Tax Incentives

\section{INTRODUCTION}

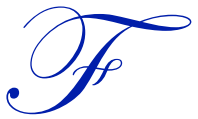

ossil fuels, such as coal, uranium, liquid fuels, and gas is abundant in South Africa. These resources play an important role in attracting investment to the country and contribute to overall socio-economic development (Department of Minerals and Energy, 1998). Despite the country's rich endowment of the mentioned fossil fuels, South Africa only has small deposits of oil and gas. These small deposits, nonetheless, play a central role in South Africa's energy supply. Following coal and peat, petroleum contributes to $12.6 \%$ of the country's total primary energy supply (EIA, 2010). Natural gas, on the otherhand, plays a major role in the production of synthetic fuels (EIA, 2010). At present, South Africa produces approximately $61.2 \%$ and $23.9 \%$ of its oil and gas needs respectively (CIA Factbook, 2015), making the country vulnerable to volatility in global fuel prices and dependent on foreign exchange to cover the country's domestic energy needs (Amigun, Musango \& Stafford, 2011). The development of domestic energy resources is therefore of utmost strategic importance to reduce this dependency as far as technically possible (Amigun et al., 2011). The relatively weak reserves position of the South African indus try may, however, change in future depending on the shale gas reserves in the Karoo. At present, it appears as if there is still significant uncertainty regarding the extent of such reserves (PetroSA, 2013; Econometrix, 2012).

Despite the importance of developing and attracting investment in the South African oil and gas industry, some obstacles to attracting such investment exist. The oil and gas industry, as with any other mining sector, require 
significant initial capital outlay. Commentators and stakeholders, therefore, argue in favor of an incentivized ope rating environment for the mining industry (Otto, Andrews, Cawood, Doggett, Guj, Stermole, Stermole \& Tilton, 2006). Any investment in this industry is captive and exposed to the risks and volatility of the host country's economy, mineral laws and policies as well as its political environment. Dupasquier and Osakwe (2006) identified the main reasons for Africa not being able to attract foreign direct investment to be political instability, poor governance, inhospitable regulatory environments, and ill-conceived investment promotion strategies, amongst others. Labor unrest and uncertainty due to continued calls for increased government interest and public ownership in the industry cripples the South African mining industry (Coetzee, 2010; Robin, 2014). The South African oil and gas industry is no exception as far as these risks are concerned. The attractivenes s of investment in this industry is further reduced by South Africa's low ranking regarding proved oil and gas reserves ${ }^{1}$, which pose an exploration risk in itself. Fluctuations between expected and actual production further illustrates high risk in the oil and gas industry. In 2011 , Business Monitor International(2011) reported that oil and gas production in South Africa grew steadily and predicted petroleum production to grow by $20.2 \%$ from 2010 to 2015 , and gas production by $40.5 \%$ within the same period. However, the production of crude oil decreased by $75 \%$ (IndexMundi, 2015) along with a decline of $64 \%$ in natural gas production (CIA Factbook, 2015) between 2008 and 2013.

The tax regime that applies can significantly affect the costs and investment risk involved in an oil and gas investment and, therefore, impact the economic viability of the investment. The need to provide an incentivized tax regime (Otto et al., 2006) to oil and gas companies was recognized by the South African government that implemented the Tenth Schedule of the Income Tax Act No. 58 of 1962 (hereafter referred to as 'the Tenth Schedule') (National Treasury, 2006). The Department of Energy (2015) highlighted that the vision of developing the petroleum industry includes the promotion of "efficient and commercially justifiable investment," as well as small businesses and employment opportunities. An investment that leads to the development of the resources is, therefore, the main goalof government, and in exchange for this, investors require a reasonable return after taxes and risks (Otto et al., 2006), which includes stability in the tax environment (National Treasury, 2006). The long-term objectives of the State, however, need to ensure that the nation's oil and gas resources are not depleted without compensating the State, as custodian of these resources under section 3(1) of the Minerals and Petroleum Resources Development Act No. 28 of 2002 (hereafter referred to as 'the MPRDA'). The achievement of this objective, while at the same time providing meaningful incentives to investors, require a fine balancing act by the State.

In light of the importance of and challenges arising from the South African oil and gas industry as set out above, the purpose of this article is to evaluate the provisions of the Tenth Schedule critically from the perspective of providing a meaningful incentive to potential investors. Rego (2003) indicated that the benefits of tax incentives are often obscure and not easily quantifiable. Luger and Bae (2005) indicated that analyzing the effectiveness of an incentive, quantitatively in a meaningful manner, is difficult due to challenges posed by the availability and suitability of dat a. Given these limitations of a quantitative analys is of a tax incentive such as the Tenth Schedule, the research method followed in this study was a conceptual analysis. The conceptual basis used for the analysis, is a framework of the fundamental characteristics of effective tax incentives from the perspectives of investors as well as the host state, as established from existing literature on this topic. The study contributes to the body of knowledge relating to the South African oil and gas industry by considering the incentivization element of the balancing conundrum, as described above, faced by the legislature.

In the remainder of this article, the characteristics of meaningful tax incentives are considered in part 2 . Part 3 provides an overview of the provisions of the Tenth Schedule. Part 4 evaluates the provisions of the Tenth Schedule with reference to the characteristics identified earlier. The article concludes with the findings of the evaluation and recommendations based on the evaluation in part 5.

\section{CHARACTERISTICS OF MEANINGFUL TAX INCENTIVES}

In South Africa's quest to promote investment growth in the oil and gas industry, an alluring regulatory environment is essential. Various forms of initiatives, such as incentives, subsidies, grant assistance programs, tax holidays and

\footnotetext{
${ }^{1}$ The country is ranked $87^{\text {th }}$ in the CIA Factbook (2015) Crude Oil Proved Reserves list, with 15 million bbl of crude oil, and $77^{\text {th }}$ in the Natural Gas Proved Reserves list, with 15.01 billion cu m of natural gas. 
discounts can be used to encourage certain actions or behaviors. One of the instruments often used by governments to lower investors' costs, and therefore also investment risk, is to provide tax incentives (Pouris, 2003). Zelinsky (1986) argued that the advantages of this instrument, compared to more direct expenditure such as subsidies, include the fact that tax incentives are more cost-effective to administer through the tax administration systemand, therefore, requires no additional implementation of laws and regulations. Also, it requires no direct cash outflow by the state.

\subsection{Classification of a Provision(s) as a Tax Incentive}

In a study on tax incentives for business investment, Zee, Stotsky, and Ley (2002) defined a tax incentive in both statutory and effective terms. In statutory terms, a tax incentive would be "a special tax provision granted to qualified investment projects that represents a statutorily favorable deviation from a corresponding provision applicable to investment projects in general." This definition would imply that any provision that applies to all projects would not constitute a tax incentive. It also focuses on the intention of governments granting the incentive. On the other hand, in effective terms, it would be "a special tax provision granted to qualified investment projects that has the effect of lowering the effective tax burden on those projects, relative to the effective tax burden that would be borne by the investors in the absence of the special tax provision." Similarly, a tax incentive was also described as "a tax reduction afforded to people for particular purposes"(CIMA, 2003). These definitions focus on the effect of the incentives on taxpayers. It implies that all tax incentives are meaningful if one uses lowering of the effective tax burden as the only criterion for a meaningful incentive. Surrey (1970) defined a tax incentive as "a tax expenditure, which induces certain activities or behavior in response to the monetary benefit available." In the context of investment in the oil and gas industry, a tax incentive would, therefore, refer to any provision to lower the tax of an investor to encourage the activity of investment in the industry. Li (2006) found that, as the tax incentive policy forms part of the host characteristics, host countries compens ate for their lack in appropriate economic conditions, such as natural resources, infrastructure, and modern technology, by offering generous incentives. Given the nature and limited deposits of oil and gas, this may be particularly true and necessary in the South African context. The explanation by the National Treasury of the reasons for introducing the Tenth Schedule, as set out in part 1 above, fit these definitions and description of a tax incentive (National Treasury, 2006). Part 4 of this article will, therefore, evaluate the Tenth Schedule as a tax incentive. To perform this evaluation, the available literature on characteristics of meaningful tax incentives is considered in the next section.

\subsection{Characteristics of Meaningful Tax Incentives}

Competition amongst governments to secure the most attractive environment for investors lead to different regions becoming closer substitutes for the location of production, resulting in investment decisions becoming increasingly responsive to incentives (Liard-Muriente, 2007). Investors are sensitive to appealing incentives if other characteristics (such as reserves and quality of reserves) are comparable. A tax regime that provides meaningful incentives to encourage investment in an industry may, therefore, be of cardinal importance to develop industry through foreign investment. Five characteristics of a meaningful tax incentive regime which will optimize the effect of the regime with the minimum harmful consequences have been identified from the literature and are discussed in more detail below. Part 4 evaluates the Tenth Schedule on the basis of these five characteristics.

\subsubsection{A Tax Incentive Should Have an Objective}

To provide for the efficient development of tax incentives, Pouris (2003) emphasized the importance of obtaining a clear definition and understanding of the intended outcome. Bugher (2004) was of the opinion that one of the concems with tax incentives is that it often grows out of political motivations without consideration to solid tax policy. Basing tax incentives on political motivations leads to tax incentives implemented for the wrong reason and without any due diligence from the legis lators on the probable impact of these incentives (Bugher, 2004). Surrey (1970) contended that an incentive should aim to serve defined outcomes which the nation wishes to achieve (action or behavior to be encouraged) and is willing to finance, rather than let the market place determine the extent to which the results will be obtained. $\mathrm{Li}$ (2006) described tax incentives as a form of State interference that causes distortion with the capital market. It is, however, important that the scope of the incentive and the resulting distortion caused should only address those factors that would influence the behavior or action to be encouraged. Otto et al. (2006) furthermore warned that such an objective should not have a short-term policy focus to the detriment of the long-term strategy. In light of this, 
Abbott (2011) cautioned against the use of a wide, overly generous incentive, which may harm the country in the long-run by impacting the State's ability to generate funding for its activities, affecting its long-term ability to provide basic services.

It is clear from the above discussion that the transparency and scope of the objective of the Tenth Schedule need to be considered critically in part 4. This objective of the Tenth Schedule, as well as the objective implied by its pro visions, should furthermore be evaluated in the context of the country's long-term strategy with regard to the development of oil and gas resources.

\subsubsection{A Tax Incentive Should be Effective}

The definition of effective is "producing a desired result" (COED, 2008). In the context of a tax incentive, this implies that it can only be said to be effective if the intended objectives (as set out in 2.2.1.) are achieved. To achieve such a desired objective, Surrey (1970) contended that the advantages of incentives should be clear and compelling to overcome the losses or costs to the State that accompany the use of even a well-structured tax incentive. He argued that cost-benefit and cost-effectiveness are essential when determining whether a fiscal program will be effective. As such, the incentive should strike a balance between risk and reward for the State as well as the investor to create the optimal regulatory environment (Sunley, Baunsgaard \& Simard, 2002). Effectiveness must, therefore, consider both parties' viewpoints.

Zelinsky (1986) stated that a meaningful tax incentive from the perspective of the investoris one that maximizes total profitability or consumer satisfaction after accounting for externalities or barriers to entry. Otto et al. (2006) explained that a tax incentive would be effective if such an incentive increases a project's return, as investors who are deciding whether to invest in a venture are largely influenced by the expected return after taxes and risks. In the case of a petroleum or gas project, the risks posed by the project may be reduced by the increased returns resulting from the incentive (Jing \& Zhao, 2010; Mukherji, Desai \& Wright, 2008). In the South African oil and gas industry, these externalities include the limited quantity of resources available as well as the risk of carrying out exploration in light of this. Oil and gas investors require that the expected return compensate them for the risk in the sector.

One of the most important benefits of developing the oil and gas sector in any country, however, remains its fiscal role of generating tax and other revenues for the government (Sunley et al., 2002). From the State's perspective, the cost to be weighed up is based on the forgone tax revenues (Surrey, 1970 and Zee et al., 2002) while the benefit is the increase in investment and development activity in the industry ( $\mathrm{Li}, 2006)$. It is submitted that this balance is incorporated in the objectives of section 2 of the MPRDA, which implies that a fiscal regime, even one that provides incentives for investors, should be properly designed to ensure that the State, as custodian of the resources, receives an appropriate share of income generated from oil and gas extraction to achieve its social and economic objectives. Costs versus benefits considerations should not be short sighted as benefits may only become evident as time passes. Costs should include direct and indirect costs (such as investment distortion (Li, 2006), adminis tration costs (Bugher, 2004) and corruption (Zee et al., 2002)) to be considered against long-term benefits (such as a sustainable mining industry (Otto et al., 2006)).

In the South African context, therefore, section 2(e) of the MPRDA specifically allows, or perhaps even requires, the State to intervene where it deems this necessary.

As all the characteristics of a meaningful tax incentive are implicitly linked to each other, the scope of the incentive also becomes relevant for evaluating the cost of the tax incentive for the State. Zee et al. (2002) argue that whenever tax incentives are erroneously granted or made available on an overly generous basis to investment projects with no positive externalities, this would impose a further cost of the regime on the State. Another dimension of the forgone revenue that is identified by Zee et al. (2002) is that the mere existence of tax incentives may open the doors to potential abuse by investors not eligible to receive them. Both of these points raised, highlight the importance of the scope of the tax incentive, which is to be tightened by anti-avoidance provisions where necessary. Bugher (2004) is of the opinion that the administrative and compliance costs of tax incentives, such as ensuring that only qualified oil and gas taxpayers take advantage of the sector's incentives, impacts costs for the State, which are often not recognized by law makers. Lastly, Zee et al. (2002) also identified that a far more serious problem with tax incentive provisions 
often relates to the mistreatment of such provisions being unofficially overlooked or even encouraged by officials charged with the responsibility of administering these incentives. Socially unproductive rent-seeking behavior may also be induced by tax incentives, as investors fortunate enough to have captured the rents, will have an inherent interest to maintain the status quo.

To evaluate this characteristic, a conceptual cost-benefit analysis of the provisions of the Tenth Schedule will be performed in part 4 from the perspective of the tax revenue to be forgone by the State and the resultant increase in returns for potential investors. Also, provisions aimed to prevent abuse of the provisions, both by investors (taxpayers) and State officials, together with the potential administrative burdens of the Tenth Schedule, will be evaluated critically.

\subsubsection{A Tax Incentive Should be Flexible, Yet Stable}

Flexibility is an important consideration in the design of effective tax incentives (Pouris, 2003). Like effectiveness, the requirements of a flexible tax incentive regime may differ between the State and an investor.

From the perspective of investors, flexibility in the tax policy so as to accommodate companies in various stages of their development, from newly founded to an established company, is vital. Similarly, a flexible incentive from the perspective of the investor should make provision for changes in the environment, technologies, policies and other is sues that did not exist at the time of investment. In other words, an investor should not be locked into a regime or be placed at a disadvantage by the application of the regime when a change in circumstances arises. Provisions allowing benefits to be carried forward when a taxpayer is not yet in a tax paying position or those determining how a change in policy or legislation will apply to existing investors are critical in this regard (Pouris, 2003).

In relation to the State's viewpoint, flexibility implies that a tax incentive regime, such as the one in the Tenth Schedule, should allow the State room for possible adjustment to the tax legislation in case of unpredictable future events. This flexibility raises the dilemma of striking a balance between flexibility for the State at the cost of certainty for the investor as policies reducing economic fluctuations may enhance growth (Staehr, 2007). Ochieze (2007) stated that, due to the huge financial implication, which the extractive industry requires and the long period of capital return, there is a desire by foreign petroleum companies to see that the host government respects the terms of contracts throughout the life of the project. Instability in fiscal obligations is likely to lead to uncertainty for investors, which in turn increases the inherent risks faced by such companies when investing in an industry (Ochieze, 2007). This risk could be so great that it could scare potential investors off completely. The State's flexibility should, however, not be compromised unnecessarily by the flexibility provided.

For purposes of evaluating this aspect of a meaningful incentive regime, the balance between flexibility and stability of the incentives contained in the Tenth Schedule will be considered in part 4.

\subsubsection{The Effectiveness of a Tax Incentive Should Regularly be Monitored}

Succeeding in passing incentives and following up to find out whether these incentives reached the intended goal are two very different, but vital, tasks in establishing effective tax incentives (Bugher, 2004). Surrey (1970) contended that the advantages of incentives should be clear and compelling to overcome the losses that accompany the use of even the well-structured tax incentive. Through monitoring of incentives in the oil and gas industry, it will be possible to determine the effect it has on the sector: does it provide the necessary investment, or could this 'loss in revenue' be better utilized in a different way? The estimated revenue costs should also be subjected to public scrutiny in the budgetary process as tax expenditures (Zee et al., 2002). Otto et al. (2006) furthermore contended that a sector can either foster or hinder growth, with the outcome largely determined by the manner in which the State uses the taxes and other funds they gain from it - implying that this relevant information should be available and assessed on a regular basis.

This characteristic of a meaningful tax incentive will be considered by evaluating the monitoring requirements in relation to the incentives allowed under the Tenth Schedule. 


\subsubsection{Tax Incentives Should be Transparent}

In the development of legislation over the years, transparency plays a key role, as the law and its application must be comprehensible for investors and the governments in a consistent manner. A lack of transparency may easily lead to the unintentional maltreatment of legislation because of the lack of understanding. Transparency in the context of tax incentives, such as the Tenth Schedule, refers to transparency in the requirements to qualify for the regime, transparency in determining the benefits available to investors and transparency in the application of the incentive for all taxpayers. Zee et al. (2002) highlighted that the qualifying criteria for tax incentives should be simple, specific and objective in order to minimize subjective interpretation and application by the administering officials of the incentive system, and to ease monitoring and enforcement of responsibilities of tax administrators.

All tax incentives should be based on the same statutory basis as relevant tax laws to avoid possible conflicts, inconsistencies, and overlaps across different laws. Additionally, the rationale for imposing these incentives should be made clear by thoroughly thought-out economic arguments, estimating the economic impact and revenue costs of granting the incentives based on clearly stated as sumptions and methodologies.

Part 4 will evaluate the provisions of the Tenth Schedule critically for potential areas where transparency and consistency in the scope, determination of the benefits and application may be lacking.

\section{AN OVERVIEW OF THE PROVISIONS OF THE TENTH SCHEDULE}

This section of the article provides a brief and high-level overview of the provisions of the Tenth Schedule to serve as context for the evaluation and findings presented in parts 4 and 5. Section 26B of the Income Tax Act No. 58 of 1962 (hereafter referred to as 'the Act') incorporates the effect of the provisions of the Tenth Schedule into the taxable income of an oil and gas company. As such, the taxable income of the oil and gas company is determined under the normal provisions of the Act, but subject to the provisions of the Tenth Schedule that modify the normal provisions to provide relief or incentives. Any reference to a paragraph in this part of the article refers to a paragraph of the Tenth Schedule unless indicated otherwise.

\subsection{Scope of the Tenth Schedule}

The provisions of the Tenth Schedule apply to oil and gas companies as defined. This term refers to a company that holds any petroleum or gas right (reconnaissance permit, technical co-operation permit, exploration right, or production right as defined in section 1 of the MPRDA or certain rights obtained by conversion) and en gages in exploration or post-exploration regarding such a right. For these purposes, post-exploration is defined as any activity carried out after the appraisal phase, but before refining.

\subsection{Relief Provisions}

Paragraphs 3(1) and 3(2) effectively provide an exemption for an oil and gas company from dividends withholding tax and interest withholding tax. The interest withholding tax exemption is however limited to loans applied to fund capital expenditure (development costs) in respect of which relief is provided.

The Tenth Schedule allows the deduction of certain expenditure that would not otherwise be deductible. Paragraph 5(1) allows any expenditure incurred in respect of exploration or post-exploration activities to be deducted from oil and gas income, whereas section 11(a) of the Act would otherwise only allow this deduction if the expenditure is not of a capital nature. Also, section 36 of the Act only allows mining companies to deduct certain specified capital expenditure, subject to mine-for-mine ring fencing. In addition to this, paragraph 5(2) makes provision for a further deduction of $100 \%$ of capital expenditure incurred in respect of exploration and $50 \%$ of capital expenditure incurred during the post-exploration phase of the project. In both these provisions, the costs relating to the acquisition of the oil and gas rights are excluded. Paragraphs 5(3), 5(4) and 5(5) however then limit the utilization of an asses sed loss of an oil and gas company to the utilization against oil and gas income or income from refining, except for $10 \%$ of the remaining loss, which may be used against other income. Paragraph 6 deems a company holding a petroleum or gas right to carry on a trade and incur expenditure in the production of income, thereby allowing deduction of costs not 
relating to exploration or post-exploration (for example, during temporary cessation of activities of rehabilitation) (National Treasury, 2013).

Oil and gas companies must determine their currency gains or losses with reference to the trans lation method used for purposes of financial reporting, thereby using its functional currency. This gain or loss will then be translated to South Africa's currency by applying the average exchange rate for the applicable year. Non-resident companies can rely on their currency as base currency for tax purposes, thereby reducing currency gain and loss taxation on the bulk of its transactions, which are likely to be denominated in a foreign currency (National Treasury, 2006).

On disposal of a petroleum or gas right, the Tenth Schedule makes provision for roll-over treatment (purchaser assumes the seller's tax cost, realizing no gain for the seller) or participation treatment (parties elect that the gain realized on disposal is treated as gross income for the seller and deductible from oil and gas income for the purchaser). These alternatives to the normal treatment are available if the parties agree to this in writing.

\subsection{Stabilization Provisions}

Paragraph 2 provides investors with the assurance that the tax imposed in respect of the taxable income of a petroleum or gas company will not exceed $28 \%$, which is the current tax rate that applies to all companies in South Africa.

Paragraph 8 contains the remaining stability provisions. A petroleum or gas company can elect to enter into an agreement with the Minister of Finance that guarantees that the provisions of the Tenth Schedule, as at the date of the agreement, will apply to the company as long as that company holds the oil or gas right. Such an agreement can also be entered into in anticipation of the granting of an oil or gas right, provided that the oil and gas right must be granted within one year from the date of the agreement. The stability afforded to a company extends to the counterparty to a joint venture or similar arrangement. Fiscal stability rights relating to an exploration right may be transferred if the company disposes of such a right to any person while fiscal stability rights relating to a production right can only be transferred to another company that forms part of the same group of companies as the disposing company. The taxpayer may elect to terminate stabilization agreements, with effect from the year of assessment following the year in which notice of termination is given. Paragraph 8(6) makes provision for compensating measures should the State fail to comply with the agreement, and the petroleum or gas company suffer an adverse economic impact as a result of this.

\section{EVALUATION OF THE PROVISIONS OF THE TENTH WITH REFERENCE TO THE CHARACTERISTICS IDENTIFIED}

Part 2 identified some characteristics of meaningful tax incentives. In this part of the article the provisions of the Tenth Schedule, as described in part 3, are evaluated against the characteristics of meaningful tax incentives to achieve the aim of this article.

\subsection{The Tenth Schedule as an Incentive with a Well-Defined Objective (Refer 2.2.1.)}

On introduction of the revised new legislation applicable to the oil and gas industry, the State's stated objective with the Tenth Schedule was emphasized as being to create an incentivized environment for oil and gas companies to lure investment to the country (National Treasury, 2006). As such, the focus of the incentive is aimed at encouraging the initial investment and development, which, once incurred, should be beneficial to the sector as well as the broader South African economy. In light of the information presented in part 1 relating to the relatively small amount of reserves and concerns regarding the quality of the reserves, this stated objective appears to address the challenge faced by the oil and gas sector in South Africa. Based on the understanding of the reason for the need for incentivization and the purpose of the incentive, the objective of the Tenth Schedule is defined. The legislation, therefore, meets the first characteristic of a meaningful incentive. 


\subsection{The Tenth Schedule as an Effective Incentive from an Investor Perspective (Refer 2.2.2.)}

As indicated in 3.2., the Tenth Schedule contains some relief measures that are not available to taxpayers not engaged in the development of oil and gas resources and clearly increases the potential returns available to investors. These relief measures in itself results in a degree of effectiveness for the investor in the manner contemplated by Otto et al. (2006). Whether this potential increase in the returns would, however, be sufficient to compensate for the level of risk involved in oil and gas projects in South Africa, as contemplated by Jing \& Zhao (2010) and Mukherji, Desai and Wright (2008), will depend on the individual investor, the investment decision, and the nature of the project. As indicated in part 1., a quantitative analysis of the incentives provided by the Tenth Schedule is beyond the scope of this article. Also, a quantitative comparison with countries that may hold similar or more attractive investment opportunities in the oil and gas sector, competing with South Africa to attract investment, would be required to be able to express a view on the impact of the incentive from the perspective of investor returns.

\subsection{The Tenth Schedule as an Effective Incentive from a State Perspective (Refer 2.2.2.)}

As indicated by Surrey (1970) and Zee et al. (2002), the risk from the State's perspective on the effectiveness of an incentive lies in, firstly, overly generous concessions, and secondly, whether the foregone revenues may assist in achieving the objective at which the incentive is aimed. The effectiveness of the Tenth Schedule is considered on these two bases on a conceptualbasis below.

In relation to the extent of and circumstances under which the State forgone revenues, the form of the relief must be considered. The main relief afforded to companies involved in oil and gas exploration involves an allowance in respect of certain capital expenditure incurred to develop the resources to a point where it can be extracted and traded commercially. The benefit of these allowances can, however, only be utilized against oil and gas income or income from refining the products (sections 5(3) to 5(5)). As such, the benefit of these allowances will only realize for an investor once the capital investment made reaps economic benefits. The incentive, there fore, only has a cost to the State if the particular project is successful, rather than the cost of unsuccessful projects eroding the tax base that arises from othernon-oil and gas project sources. The incentive would, if it is indeed successful in luring investors to develop South Africa's oil and gas resources, effectively encourage investors to bear all the risk associated while developing the nation's resources. The design of the Tenth Schedule, therefore, results in the State bearing development risk while the cost is limited to the State giving up a portion of its share of the wealth gained from successfuldevelopments. In the absence of such an incentive, the State may be required to bear development risk if the nation's resources are to be developed. The incentive is therefore effective in the sense that it relieves the State from bearing initial development risk and the costs associated with it, in exchange for forgoing revenue on successfulprojects. As such, the incentive does not involve a cost to the State without any identifiable benefit. As indicated by Rego (2003) it is likely to be challenging, if not impossible, to as sess the cost-benefit effect of the incentive to the State quantitatively.

As indicated in 4.1., the objective of the incentive in the Tenth Schedule is to create an incentivized environment for oil and gas companies to lure investment (National Treasury, 2006). As such, it is important that the relief afforded by the State is focused on and limited to such investment and development activities. The allowances afforded in respect of capital expenditure to be incurred align with this objective. A recent IMF report (IMF, 2015) describes these allowances as generous. The same study, however, qualifies this statement by referring to the nature and quality of the resources that the activity will relate to as justification for these generous allowances. The magnitude of the allowances is, however, not necessarily excessive in light of the limited resources available. The fact that the concessions are limited to exploration and post-exploration activities, but do not extend to refining, illustrates that the focus of the incentive does not cover all phases of the life of the mine but are limited to those to be encouraged. A similar focus is the exemption from the withholding tax on interest where such interest is incurred in respect of loans to fund development costs. The exemption from the dividends tax may arguably result in more generous benefits to equity investors and is not explicitly limited to equity investments to fund development costs. Equity funding, which does not potentially erode the tax base through interest deductions that may arise from debt funding once a project is profitable, should, however, be encouraged (National Treasury, 2006). As such, the wider scope of this part of the incentive is not neces sarily a shortcoming. Lastly, the rollover treatment afforded to oil and gas companies on disposal of oil or gas rights may be critical in ensuring continued development when requiring further funding in the case of a 
project that may need to be transferred into a different investment vehicle (National Treasury, 2006). No element of the incentive appears to be overly generous or unfocussed based on the above analysis.

\subsection{The Tenth Schedule as a Stable Incentive (Refer 2.2.3.)}

As indicated by Ochieze (2007), stability from an investor perspective is closely related to certainty as to the fiscal regime applicable to the investment made by the oil and gas company. Although the provisions of the stabilization clauses in the Tenth Schedule seems open-handed and generous, Futter (2010) identified some short-comings of the current fiscal stability agreement included in the Tenth Schedule in comparis on with the previous regime. First ly, the agreement does not encompass all taxes (over and above income tax) levied on an oil and gas company. Also, it does not protect an investor against the introduction of new taxes to the oil and gas sector. The introduction of the Mineral and Petroleum Resources Royalty in 2010 is a good example of such a tax that investors may not have bargained on when investing before this date (Minerals and Petroleum Resources Royalty Act No. 28 of 2008 ('Royalty Act')).

This clause also does not protect against amendments in the body of the Act (OPASA, 2010). An example of such an amendment that impacts an oil and gas company is the introduction of section 23M of the Act (hereafter referred to as ' $23 \mathrm{M}$ '), which may impose a limit, in addition to thin capitalization provisions, in respect of interest incurred towards foreign-connected pers on funders. In the case of section $23 \mathrm{M}$, the overall deductibility of the interest incurred over the duration of the project may not be affected, but the timing of the deduction, which impacts directly on when investors will receive returns, may be impacted. The timing of the deduction would be an issue despite the fact that paragraph 6 of the Tenth Schedule previously contained a safe harbor in relation to this capitalization require ment. This analysis and example, therefore, illustrate that despite the fact that the tax rates (corporate tax at 28 per cent and dividends tax at zero per cent) have been locked in, the base to which these rates are applicable is not protected by a fiscal stability arrangement.

The interaction between the provisions of the body of the Act and those of the Tenth Schedule arguably causes further uncertainty as it creates complexity to be navigated and understood by potential investors. An example of this complexity is the question whether the normal mining provisions, including mine by mine ring-fencing in section 36 of the Act, apply to an oil and gas company seeing that the Tenth Schedule is still applied in the framework of the Act as a whole. The answer presumably depends on whether oil and gas activities contrite mining operations, which is defined as "every method or process by which any mineral is won from the soil or from any substance orconstituent thereof." This determination would, in turn, depend on whether petroleum or gas constitutes a mineral or not. The fact that other legislation, such as the MPRDA distinguishes between minerals and petroleum would suggest that petroleum is not considered to be a mineral. As indicated, the purpose of the MPRDA differs from the Act and the terminology may not necessarily be of use in interpreting the Act (SARS, 2015). The intention is found in an explanatory memorandum that accompanied the introduction of the Tenth Schedule where it is explained that the allowa nces under paragraph 5 of the Tenth Schedule are only available to be used against income from oil or gas activities, but is not ring-fenced on well by well basis. This complexity, however, adds uncertainty to be resolved and possibly significant costs to be incurred in the process by investors.

\subsection{The Tenth Schedule as a Flexible Incentive for the State (Refer 2.2.3.)}

The potential shortcoming of stability for an investoridentified in 4.4. is the characteristic of the Tenth Schedule that provides the State with flexibility in the regime despite the fact that tax rates have been locked in. Despite this flexibility arising from provisions in the remainder of the Act, the IMF found (IMF, 2015) that the current regime and benefits may be difficult to maintain should successfuldiscoveries increase, yet the State may at that point be locked into numerous stability agreements that guarantee the allowances discussed in 3.2. above. This difficulty may however to a large extent be negated by the fact that the stability agreement is in terms of paragraph $8(1)$ of the Tenth Schedule in respect of an oil or gas right, as opposed to for the life of an oil or gas company and all its future activities. The wording of paragraph 8(1) furthermore affords the State discretion in the decision to enter into an agreement that locks in the provisions of the Tenth Schedule as it states that the Minister may enter into such an agreement. Based on this analysis, read in light of the concerns regarding certainty and stability for investors in 4.4. the current provisions of the Tenth Schedule, therefore, appear to provide sufficient flexibility to the State for both existing agreements as well as the entering into new stability agreements. 


\subsection{The Tenth Schedule as a Well-Monitored Incentive (Refer 2.2.4.)}

Surrey (1970) stated that it is probable that investment projects would still be undertaken even in the absence of tax incentives. Typically, the projects with tax incentives are those with the highest profitability, and therefore also economic merits, and tax incentives represent free gifts to these investors. Successful oil and gas companies may generate a substantial profit. Examples include PetroSA's net profit margin of 39.86\% in 2006 (PetroSA, 2007). Alternatively, it can be argued that no oil and gas activity will be encouraged in the absence of tax incentives due to the high risk and volatility involved as discussed in section 1. The volatility is illustrated by the same, previously highly profitable company PetroSA, which made a loss of R14.3 billion in 2015 that lead to a negative net profit margin of $79 \%$ (PetroSA, 2015). Therefore, in the absence of tax incentives, it will not be possible to optimize available oil and gas resources to benefit the community of South Africa, which will fall short of the aim of the MPRDA as mentioned earlier. As identified in 4.2., it may be difficult to determine the turning point when the investment prospects are such that the investment would have been made despite the absence of an incentive. This difficulty is not problematic at present with the low number of discoveries to date. In light of developments in the sector, for example, should there be significant discoveries of shale gas reserves in the Karoo Basin, the importance of evaluating the need for an incentivized environment may become much greater in future. In relation to monitoring the effectiveness of the Tenth Schedule, this incentive lacks reporting requirements that are found in other incentives contained in the Act, for example, the research and development incentive in section 11D, which has reporting requirements in section $11 \mathrm{D}(17)$, or the urban development zones incentive in section 13quat, which requires reporting under section 13quat(11). Based on the lack of any apparent monitoring mechanism, at least from the provisions of the Tenth Schedule, it is recommended that further research into the effectiveness and design of such a reporting requirement may be warranted.

\subsection{The Tenth Schedule as a Transparent Incentive (Refer 2.2.5.)}

At the time of the introduction of the Tenth Schedule, the National Treasury (2006) advanced that the motivation for the move away from the previous OP26 regime was due to uncertainty around the renewal of the fiscal provisions contained in OP26, which led to certain companies postponing any further investment until this vagueness was resolved. The government's aim with the Tenth Schedule was to create transparency and certainty for the taxation of oil and gas exploration and production, by formalizing key aspects of OP26 into explicit law (National Treasury, 2006). The provisions of the Tenth Schedule appears to be successful in establishing objective criteria and definitions that regulate the taxpayers who would benefit from the regime. As such, it meets the criteria identified by Zee et al. (2002) that the requirements to qualify for the incentive should be simple, specific and objective and minimize the need for subjective interpretation.

As indicated in 4.5., a degree of discretion is involved when it comes to the decision of the Minister to enter into a fiscal stability agreement with a specific taxpayer. This discretion is, however, limited to the decision to enter into the agreement that locks in the current benefits of the Tenth Schedule or not, as opposed to being able to negotiate a unique taxing regime with a taxpayer that differs from the provision of the Tenth Schedule that apply to all other oil and gas companies. This discretion, therefore, protects the State from being bound by the generous provisions of the Tenth Schedule, should discoveries increase, as was warned by the IMF (2015).

\section{CONCLUS ION}

The research conducted in this study aimed to determine whether the Tenth Schedule in South Africa provides sufficient incentive to oil and gas companies to compete for international investment in this industry. To determine whether South Africa will be able to employ tax incentives as a means of luring investment to the country, the role and characteristics of meaningful tax incentives were considered in part 2. These characteristics were then used to evaluate South Africa's income tax legislation that currently applies to the oil and gas industry to, to identify available tax incentives, in part 4.

The conceptual analys is of the provisions of the Tenth Schedule against the characteristics of meaningful incentives as identified from the literature revealed that the Tenth Schedule is well designed as it has a clear objective and alignment exists between the areas where relief is afforded and the stated objective. These benefits are granted in 
objectively identifiable instances, and discretion is minimized to decisions whether fiscal stability agreements are entered into by the State or not. These decisions provide the State with flexibility in relation to stability benefits provided to specific projects and also a mechanism to prevent being locked into a regime that may be too generous if discoveries were to increase. Also, it can be argued that the incentive results in investors bearing the risk of development while the State only incurs costs in the form of forgone revenue if projects are successful. As such, the incentive appears to strike a justifiable balance between costs and benefits for the State. The conceptual analysis, however, identified the following areas of the Tenth Schedule where it may fall short of being a meaningful incentive, and which could warrant further research:

1. Fiscal stability agreements provide investors with certainty of the aspects contained in the Tenth Schedule only, mainly, the tax rates and allowances. It does, however, not provide investors with certainty about the tax base to which these rates are applicable. New developments, such as the introduction of section 23M, may have a significant impact on this base.

2. The interaction between the Tenth Schedule and the Act as a whole may result in complexities that cause uncertainty with investors. This uncertainty could result in perceived instability. Solutions to resolve this finding should be considered and may be as simple as the is suing of an interpretation note that explains the interaction or as complex as a re-write of parts of the legislation.

3. The Tenth Schedule contains no apparent monitoring measure to determine the impact of the incentive. A monitoring measure might become more important if discoveries were to increase. It is recommended that further research be performed on measures implemented elsewhere to monitor the impact of an incentive or the use of reporting requirements, such as the ones contained in other incentives in the Act, in the context of the Tenth Schedule.

\section{AUTHOR BIOGRAPHIES}

Anneke Maré Moolman is a chartered accountant (CA(SA)) and holds a master's degree in taxation from the NorthWest University. She is a senior lecturer at the North-West University in Vanderbijlpark (South Africa) where she is responsible to present auditing on a pre- and postgraduate level and supervise research in accountancy. E-mail: anneke.moolman@nwu.ac.za (contact author)

Pieter van der Zwan is a chartered accountant (CA(SA)) and holds a master's degree in taxation from the University of Pretoria. He is an associate professor at the North-West University in Potchefstroom (South Africa) where he is responsible to present the master's degree programme in taxation and supervise tax research. E-mail: pietervanderzwan@nwu.ac.za

\section{REFERENCES}

Abbott, P. (2011). The Impact of Tax Incentives in East Africa - Rwanda case study report: Avoiding Tax Competition and the "Race to the Bottom". Institute of Policy Analy sis and Research-Rwanda.

Amigun, B., Musango, J. K. \& Stafford, W. (2011). Biofuels and sustainability in Africa. Renewable \& Sustainable Energy Reviews, 15(2),1360-1372, February.

Bugher, M. D. (2004). Comments on the value of State tax incentives. Marquette Law Review, 88: 129-133, May.

Business Monitor International. (2011). South Africa Oil and Gas Report. Business Monitor International, 27. Pub ID: BMI6579262.73p. Retrieved 27/10/11 from http://www.marketresearch.com/Business-Monitor-Internationalv304/South-Africa-Oil-Gas-Q4-6579262

Central Intellegence Agency. (2015). Retrieved 8/12/15 from https://www.cia.gov/library/publications/the-world-factbook/

CIA Factbook see Central Intellegence Agency.

CIMA Dictionary of Finance and Accounting. (2003). London: Bloomsbury.310p.

CIM A see CIM A Dictionary of Finance and Accounting.

COED see Concise Oxford English Dictionary.

Coetzee, C. (2010). The Proposed Nationalisation of Mines in South Africa - A Critical Assessment. 80p.

Concise Oxford English Dictionary. (2008). Oxford, N.Y.: Oxford University Press. 1681p.

De Koker, A. P. (2011). Silke on South African Income Tax. South Africa (Electronic version).

Department of Energy see South Africa. Department of Energy.

Department of Minerals and Energy see South Africa. Department of Minerals and Energy. 
Dupasquier, C. \& Osakwe, P.N. (2006). Foreign Direct Investment in Africa: Performance, Challenges, and Responsibilities. Journal of Asian Economics, 17, 241-260.

Econometrix. (2012). Retrieved 8/12/15 from http://cer.org.za/wp-content/uploads/2012/06/Econometrix-KSG-Report-February2012.pdf

EIA see Energy Information Administration.

Energy Information Administration. (2010). Retrieved 29/08/11 http://www.eia.gov/emeu/cabs/South_Africa/pdf.pdf

Futter, A. J. (2010). The taxation of oil and gas exploration and production in South Africa: A critical comparison of the OP26 and the Tenth Schedule tax regimes. Cape Town: University of Cape Town. (Dissertation - M. Com.) 123p.

IMF see International Monetary Fund.

Indexmundi. (2015). Retrieved 9/12/15 from http://www.indexmundi.com/energy .asp x?country=za\&product=oil\&graph=production-growth-rate

International Monetary Fund. (2015). South Africa Technical Assistance Report - Fiscal Regimes for Mining and Petroleum: Opportunities and Challenges. 154p. Retrieved 9/12/15 from https://www.imf.org/external/pubs/ft/scr/2015/cr15244.pdf

Jing, T. \& Zhao, H. (2010). Value at Risk and Hedge Fund Return - Does High Risk Bring High Return? 32p.

Langhus, J. (2010). OPASA: Proposal: Transfer of Fiscal Stability Agreement Rights. Cape Town: OPASA. Proposal to National Treasury.

Li, Q. (2006). Democracy, Autocracy, and Tax Incentives to Foreign Direct Investors: A Cross-National Analy sis. The Journal of Politics, 68(1), 62-74, February.

Liard-Muriente, C. F. (2007). US and EU experiences of tax incentives. Area, 39(2), 186-194.

Luger, M, \& Bae, S. (2005). The Effectiveness of State Business Tax Incentive Programs: The Case of North Carolina. Economic Development Quarterly, 19, 327 - 345.

MPRDA see South Africa. (2002).

Mukherji, A., Desai, A. B. \& Wright, P. (2008). A Contingent Relationship Between Risk and Return: Toward a Behavioral Model of Decision Making. Institute of Behavioral and Applied Management, 240-257.

National Treasury see South Africa. Department of National Treasury.

Ochieze, C. (2007). Fiscal Stability: To what extent can fiscal stability mitigate changing circumstances in a petroleum tax regime? OGEL. 5(2).

OPASA see Langhus, J.

Otto, J., Andrews, C., Cawood, F., Doggett, M., Guj, P., Stermole, F., Stermole, J. \& Tilton, J. (2006). Mining Roy alties: A Global Study of Their Impact on Investors, Government and Civil Society. Washington D.C.: The World Bank. 296p.

Petroleum Agency SA. (2013). Retrieved 7/12/15 from http://www.petroleumagency sa.com/index.php/home-14/shale-gas

Petroleum Agency SA. (2007). Annual Financial Statements 2007. 163p.

Petroleum Agency SA. (2015). Integrated Annual Report 2015. 172p. Retrieved 9/12/15 from www.petrosa.co.za/Documents/JOB06875_PetroSA_IAR.PDF

PETROSA see Petroleum Agency SA.

Pouris, A. (2003). Towards a South African R\&D tax incentives scheme: fiscal policies and social benefits. South African Journal of Science, 99, 195-199, May/June.

Rego, S.O. (2003). Discussion of the effect of State income tax apportionment and tax incentives on new capital expenditures. Journal of the American Taxation Association, 25, 27-32.

Robins, S. (2014). Slow Activism in Fast Times: Reflections on the Politics of Media Spectacles after Apartheid. Journal of Southern African Studies, 40(1), 91-110, March.

Roy alty Act see South Africa. (2008).

SARS see South African Revenue Service.

South Africa. (1962). Income Tax Act No. 58 of 1962. Pretoria: Government Printer.

South Africa. (2002). Minerals and Petroleum Resources Development Act 28 of 2002. Pretoria: Government Printer.

South Africa. (2008). Minerals and Petroleum Resources Roy alty Act 28 of 2008. Pretoria: Government Printer.

South Africa. Department of Energy . (2015). Retrieved 8/12/2015 from http://www .energy.gov.za/files/petroleum_frame.html

South Africa. Department of Minerals and Energy. (1998). White Paper on the Energy Policy of the Republic of South Africa. Pretoria: Government Printer. 110p. (WPB-1998).

South Africa. Department of National Treasury. (2006). Explanatory Memorandum on the Revenue Laws Amendment Bill, 2006. Pretoria: Government Printer. 103p. Retrieved 8/12/15 from http://www.sars.gov.za/AllDocs/LegalDoclib/ExplMemo/LAPD-LPrep-EM-2006-01\%20\%20Explanatory\%20Memorandum\%20Revenue\%20Laws\%20Amendment\%20Bill\%202006.pdf

South Africa. Department of National Treasury. (2013). Explanatory Memorandum on the Revenue Laws Amendment Bill, 2013. Pretoria: Government Printer. 145p. Retrieved 9/12/15 from http://www.sars.gov.za/AllDocs/LegalDoclib/ExplMemo/LAPD-LPrep-EM-2013-02\%20\%20Explanatory \%20M emorandum\%20Taxation\%20Laws\%20Amendment\%20Bill\%202013.pdf

South African Revenue Service. (2015). Draft Interpretation Note: Whether Certain Quarrying Operations Constitute Mining Operations. 20p. Retrieved 8/12/15 from http://www.sars.gov.za/AllDocs/LegalDoclib/Drafts/LAPD-LPrep-Draft- 
2015-09\%20-\%20Draft\%20IN\%20Whether\%20certain\%20quarry ing\%20operations \%20constitute\%20mining\%

20operations.pdf

Staehr, K. (2007). Fiscal Policies and Business Cycles in an Enlarged Euro Area. CESifo Working paper No. 1933. Category 5: Fiscal Policy, Macroecomics and Growth. February 2007. 33p.

Sunley, E.M., Baunsgaard, T.\& Simard, S. (2002). Revenue from the Oil and Gas sector: Issues and country experience. Washington: International Monetary Fund.

Surrey, S. S. (1970). Tax Incentives as a Device for Implementing Government Policy: A Comparison with Direct Government Expenditures. Harvard Law Review, 83(4), 705-738, February.

The Act see South Africa. (1962).

Zee, H. H., Stotsky, J. G. \& Ley, E. (2002). Tax Incentives for Business Investment: A Primer for Policy Makers in Developing Countries. World Development, 30(9), 1497-1516.

Zelinsky, E. A. (1986). Efficiency and Income Taxes: The Rehabilitation of Tax Incentives. Texas Law Review, 64, 973-1037. 


\section{NOTES}

